\title{
Comparison of Macroheterocera assemblages of four forests in the Bereg Plain (Hungary, Ukraine)
}

\author{
Szabolcs Szanyi ${ }^{1,3}$, Antal NagY ${ }^{2}$ \& Zoltán VARgA ${ }^{1}$ \\ ${ }^{1}$ Department of Evolutionary Zoology, Faculty of Science and Technology, University of Debrecen, Hungary; \\ e-mail: szanyiszabolcs@gmail.com \\ ${ }^{2}$ Institute of Plant Protection, Faculty of Agricultural and Food Sciences and Environment Management, University of \\ Debrecen, Hungary
}

\begin{abstract}
We compared the macro-moth assemblages of four forests from which one is extended on the Ukrainian and three on the Hungarian side of the Bereg lowland, and additionally one in the adjacent part of the Hungarian plain (NE of Carpathian Basin). The data were collected by light trapping during at least in five years in all sites. Numerous faunistically significant and/or rare species were recorded. The species composition, faunal types and ecological components were rather similar in all sites, dominated by widely distributed Euro-Siberian species but with considerable participation of BoreoContinental and Holo-Mediterranean - West Asiatic species. Considering the ecological connections of the species, the largest part of the assemblage is composed by species of different types of deciduous forests (oak woods and hardwood gallery forests) but also with significant proportion of wetland components (marshy-boggy habitats and tall forb communities) and generalist species. The similarity of the species composition proved to be high in all dominant taxonomical groups (Geometridae, Erebidae and Noctuidae, including the most diverse subfamilies). Several species have high conservation significance.
\end{abstract}

Key words: night-active; macro-moths; hardwood forests; biogeography; ecological grouping; faunal similarity; light trapping.

\section{Introduction}

The Bereg plain, a part of the Transcarpathian lowland, is located in the northeastern edge of the Pannonian lowland and is extended on both sides of the Hungarian-Ukrainian border. Until the early $20^{\text {th }}$ century this lowland area was characterised by the wide floodplains of the river Tisza and tributaries but also by the presence of boggy areas in the former oxbow-lakes, as the transitional bogs of Ecsed and Szernye. As a consequence of the regulation of waterways and drainage of most wetlands, these formations became extinct and a traditional cultural mosaic landscape was formed with arable lands, pastures and hayfields and more or less extended but fragmented patches of the natural or seminatural vegetation. As a result of these processes this region is relatively rich in forests and humid habitats and also in relict plant species from cold or cool climatic phases (Hargitai, 1943; Simon 1957, 1960).

The Bereg lowland represents the coolest and mostly humid part of the Great Pannonian Plain with expressed continental character (Baranyi 2009). The average of annual temperature is $8.9^{\circ} \mathrm{C}$, the mean temperature of January is $-3.2^{\circ} \mathrm{C}$, of July $20.1^{\circ} \mathrm{C}$, thus the yearly fluctuation is between $23-24^{\circ} \mathrm{C}$. The average annual precipitation is $609 \mathrm{~mm}$ with a maximum in June $(74 \mathrm{~mm})$ and November $(55 \mathrm{~mm})$. It means that the climate of the Bereg Plain is strongly different from the semi-humid forest-steppe climate of the most part of the Pannonian lowland and belongs to the ' $D$ ' climatic zone according to the Köppen-system (Zólyomi 1958). The dominant natural vegetation types of the Bereg Plain were the pedunculate oak-hornbeam climax forests (Circaeo-Carpinetum) and the hardwood gallery forests (Fraxino pannonicae-Ulmetum) with highly diverse floristic composition both in canopy and shrub layer. These forests preserved a large number of plant and invertebrate species which are distributed in the Carpathian basin mostly in montaneous regions and in the adjacent Carpathians.

The variety of vegetation types supports the high diversity of fauna in the land gastropods and also in most insect groups. As typical Carpathian elements can be mentioned, e.g., the snails Bielzia coerulans M. Bielz, 1851*, Oxychilus orientalis (Clessin, 1887), Perforatella dibothryon M. Kimakowicz, 1884*, Perforatella vicina (Rossmässler 1842)*, Ruthenica filograna (Rossmässler, 1836), while the snails Drobacia banatica (Rossmässler, 1838)* Lozekia transsylvanica (Westerlund, 1876), the bush-crickets Isophya stysi Cejchan, 1957*, Leptophyes discoidalis (Frivaldszky, 1868), Pholidoptera transsylvanica (Fischer, 1853)*, the grasshopper Odontopodisma rubripes (Ramme, 1931)* and the ground beetle Carabus hampei Kuster, 1846* 
represent the Dacian faunal elements. Some of the mentioned species (marked with $*$ ) are also included in the Annexes II-IV of the Habitats Directive. They occur in largest number at the site four (Kaszonyi Hill). The presence of these faunal elements clearly shows that this part of the lowland represents a biogeographically transitional belt between the Pannonian and Carpathian regions, called Praecarpathicum (Deli et al. 1997; Magura et al. 1997; Ködöböcz \& Magura 1999; Varga 1995, 2003; Fekete \& Varga 2006; Nagy et al. 2015). Several groups of Invertebrates were intensively surveyed in the Hungarian part of the lowland (e.g., Gastropoda, Odonata, Ephemeroptera, Orthoptera, Coleoptera: Carabidae, Trichoptera, Macrolepidoptera) while the Ukrainian part is entomologically much less known. The Game Reserve at Velyka Dobron' constitutes an exception since the first communications on the Orthoptera and Lepidoptera assemblages of this area are already published (Szanyi 2015; Szanyi \& Varga 2015; Szanyi et al. 2015).

There are several larger forests in this region which are protected at different levels. Three of them, the Game Reserve at Velyka Dobron' (Ukraine), the NATURA 2000 sites Bockerek and Lónyai forests (Hungary) are very similar to each other in their vegetation types. The fourth protected site, the island-like Kaszonyi-hill shows several differences in the composition of vegetation. Additionally we could compare these forests with a rather intensively surveyed nature conservation area lying less than $100 \mathrm{~km}$ South of the most northern site (Fig. 1). However, at present the extension of these and other forests cover only less than $20 \%$ of the area. Therefore, we were interested in, whether these more or less isolated forests could preserve the Macroheterocera species composition typical for different types of forests. We also aimed to compare the proportions of biogeographical types and ecological components of Lepidoptera in these forests. We could use lists of species which were collected at least in five years and with generally the same method (light trapping).

\section{Material and methods}

\section{Characterisation of the study areas}

Forest of the Game Reserve of Velyka Dobron' (1) The area of the surveys was the Velyka Dobron' (Nagydobrony) Game Reserve $\left(48^{\circ} 24^{\prime} 07^{\prime}{ }^{\prime}-48^{\circ} 26^{\prime} 25^{\prime \prime} \mathrm{N} ; 22^{\circ} 24^{\prime} 07^{\prime \prime}\right.$ $22^{\circ} 25^{\prime} 51^{\prime \prime} \mathrm{E}$ ), founded in 1974 by the government of the former Ukrainian Soviet Socialist Republic in an extension of more than 1700 ha. The study site is located on the marginal area of the former Szernye peatland. Although the ancient flora and vegetation of the peatland was extremely rich and valuable, the most important relict habitats and species became extinct. The area is dominated by some components of the original forest and wetland vegetation. An extended oakash-elm hardwood gallery forest represents most important nature-like habitat type of the reserve. The canopy coverage is between $70-100 \%$ and is formed by several broadleaved tree species: Quercus robur, Fraxinus angustifolia subsp. pannonica, Ulmus laevis, Populus canescens, Frangula alnus, etc. The pedunculate oak-hornbeam forest (CircaeoCarpinetum), dominated by $Q$. robur and Carpinus betu-

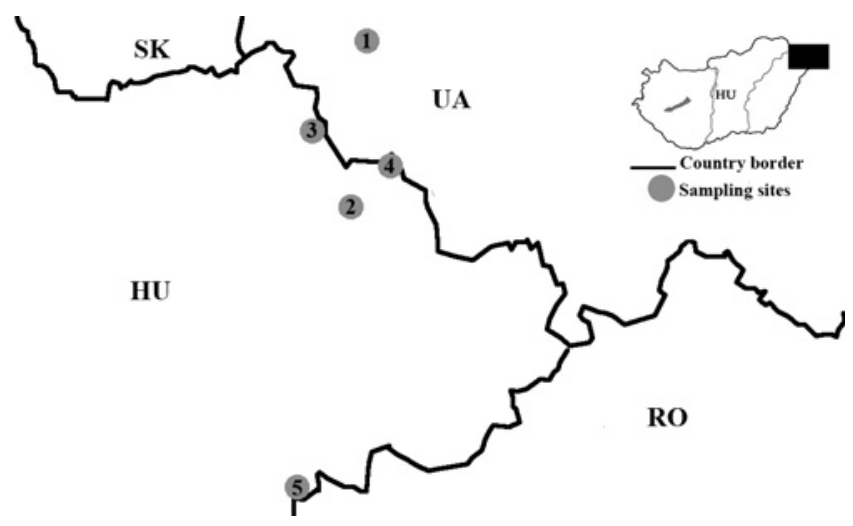

Fig. 1. Location of the sampling sites. 1 - Velyka Dobron'; 2 Bockerek; 3 - Lónyai-forest; 4 - Kaszonyi-hill; 5 - Bátorliget.

lus, is rich in geophytic species (Scilla drunensis, Anemone nemorosa, A. ranunculoides, Isopyrum thalictroides, etc.) and represents the climax association of the region. Other components of the nature-like and semi-natural vegetation are the more xerophilous silver lime (Tilia tomentosa) - oak forests and forest fringes, the mesic and humid forest clearings and willow scrubs. The reserve is surrounded by extended agricultural areas and dissected by dreanage channels of the former peatland.

Bockerek-forest near Vámosatya village (2)

The "Bockerek" is the largest forest (600 ha) on the Hungarian side of the Bereg plain $\left(48^{\circ} 09^{\prime} 41^{\prime \prime}-48^{\circ} 11^{\prime} 29^{\prime \prime} \mathrm{N}\right.$; $22^{\circ} 22^{\prime} 44^{\prime \prime}-22^{\circ} 24^{\prime} 59^{\prime \prime}$ E) extending between the villages Vámosatya $(\mathrm{N})$ and Tákos (S). The area is well known due to its rich wildlife (e.g., Booted Eagle, Black Stork, Adder) and its largest part is protected forest reserve. The main associations are nearly the same as of the former site: pedunculate oak-hornbeam forest and oak-ash-elm hardwood gallery forest, both with mixed canopy (Quercus robur, Carpinus betulus, Fraxinus angustifolia subsp. pannonica, Ulmus campestris, Acer campestre, A. platanoides), with patchy occurrence of other broadleaved trees (Quercus cerris, Cerasus avium, Pyrus pyraster, Sorbus torminalis, Populus alba) and with dense and diverse shrub layer (Acer tataricum, Cornus sanguinea, Corylus avellana, Crataegus monogyna, Ligustrum vulgare, Prunus spinosa, etc.). The periodically inundated parts of the forests are dominated by Alnus glutinosa, Salix spp. and Rubus spp. The forest is surrounded by extended, partly abandoned pastures and partly mowed tall grass-tall forb (with Peucedanum officinale) humid meadows.

Lónyai-forest near Tiszakerecseny village (3)

This is the second largest forest (470 ha) on the Hungarian side of the Bereg plain $\left(48^{\circ} 15^{\prime} 07^{\prime \prime}-48^{\circ} 18^{\prime} 10^{\prime \prime} \mathrm{N} ; 22^{\circ} 21^{\prime} 55^{\prime \prime}-\right.$ $\left.22^{\circ} 27^{\prime} 36^{\prime \prime} \mathrm{E}\right)$. It is extended East of the villages Tiszakerecseny, Mátyus and Lónya and bordered by the creek of Csaronda and crossed by the state boundary of Hungary and Ukraine. Main part of the forest is in nearly natural condition as a Natura 2000 site, although partly damaged by the overpopulated wild boar and red deer. The largest part of the forest is constituted by the same associations as in the Bockerek-forest, the pedunculate oak-hornbeam and the oak-ash-elm hardwood gallery forest with nearly continuous transitions. The dominant species of the canopy are mostly the same and also the structural characters of the stands are very similar. The herbaceous layer is characterised by some rare geophyta (Gagea spathacea, Leucojum vernum, Scilla 
kladnii) and further species which mostly occur in Hungary in montane forests (Actaea spicata, Anemone nemorosa, Asarum europaeum, Isopyrum thalictroides, Lathraea squamaria, Majanthemum bifolium, Sanicula europaea, etc.). A deeper lying part of the forest is formed by a marshy forest type (Dryopteridi-Alnetum), rich in rare fern (Dryopteris carthusiana, D. cristata, Thelypteris palustris) and sedge (Carex elongata, C. gracilis, C. pseudocyperus, C. vesicaria) species. Due to this richness of flora the forest supports also a high species diversity in most insect groups.

\section{Kaszonyi-hill near Barabás village (4)}

The site of the survey (170 ha) extends on the eastern side of the small volcanic hill (198 $\mathrm{m}$ a.s.l.) crossed by the state boundary of Hungary and Ukraine $\left(48^{\circ} 14^{\prime} 41^{\prime \prime}\right.$ $\left.48^{\circ} 15^{\prime} 13^{\prime \prime} \mathrm{N} ; 22^{\circ} 28^{\prime} 51^{\prime \prime}-22^{\circ} 29^{\prime} 31^{\prime \prime} \mathrm{E}\right)$. The hill is covered mostly by a mosaic of dry sessile oak (Quercus petraea ssp. petraea and ssp. dalechampii) - silver lime (Tilia tomentosa) forest, nature-like and semi-natural rupicolous, dry and mesic swards, fragmented black locust (Robinia pseudacacia) plantations and mostly abandoned orchards and vineyards. The forest consists of broadleaved tree and shrub species as Acer campestre, A. tataricum, Carpinus betulus, Cornus sanguinea, Crataegus monogyna, Ligustrum vulgare, Prunus spinosa, Rubus spp., Tilia cordata, Ulmus campestris, etc. The forest fringes are rich in xerophilous forest-steppic species as Geranium sanguineum, Lathyrus niger, Buglossoides purpureo-coeruleum, Lembotropis nigricans, Peucedanum cervaria, Trifolium alpestre, Vicia cassubica. On the slopes there are some volcanic rupicolous patches with following species: Festuca valesiaca, Arabis turrita, Asparagus officinalis, Bupleurum falcatum, Clematis recta, Coronilla varia, Dianthus carthusiana, Inula ensifolia, Sedum maximum, Silene nutans, Teucrium montanum, Vincetoxicum hirundinaria, Viscaria vulgaris. The site is rich in protected species, included into the Annex II-IV of the Habitats Directive. (see Introduction).

\section{Fényi-forest near Bátorliget village (5)}

The forest, extending East of the village Bátorliget $\left(47^{\circ} 41^{\prime}\right.$ $41^{\prime \prime}-47^{\circ} 44^{\prime} 59^{\prime \prime} \mathrm{N} ; 22^{\circ} 24^{\prime} 17^{\prime \prime}-22^{\circ} 17^{\prime} 36^{\prime \prime} \mathrm{E}$ ), is the largest (270 ha) and botanically most important forest of the sandy area of "Nyírség". More than one-half of the forest is composed by two dominant forest types: the mesophilous climax association of the northern sandy areas of the Pannonian lowland (Convallario-Quercetum roboris) and the Pannonian oak-ash-elm hardwood gallery forest (Fraxino pannonicae-Ulmetum) with nearly continuous transitions according to the relief of the site. The dominant broadleaved trees and shrubs are nearly the same as in the sites $1-3$, but some species occur in a larger proportion as Populus alba, Tilia tomentosa, T. platyphyllos, Ulmus laevis. In the deeper parts of the forest there are some boggy alder (Alnus glutinosa) stands with admixture of Frangula alnus, Salix cinearea, S. pentandra, Viburnum opulus and also with some inbedded marshy-boggy meadows dominated by Carex spp. The forest has plenty of protected plant species (Allium ursinum, Lathrea squamaria, Leucojum aestivum, Lilium martagon, Listera ovata, Orchis militaris, Platanthera chlorantha, Scilla drunensis) but due to partial desiccation and degradation locally also some acidophilous (Pteridium aquilinum), nitrophilous (Alliaria petiolata, Chelidonium majus, Urtica dioica) and invasive (Impatiens parviflora) species occur in large numbers. A significant part of the forest is a strict nature protection area and forest reserve.

\section{Methods of data collection and analysis}

Data were collected in all sites by light trapping, partly by fixed light trap (Jermy type) functioning with mercury vapor bulb of 125 W (Bockerek, Velyka Dobron', partly; Bátorliget: Fényi-forest, partly) and with the same but mobile light source in front of a large white sheet (Velyka Dobron', partly; Lónyai-forest, Kaszonyi-hill, Bátorliget: Fényi-forest, partly). Since the methods and also the intensity of collection were different, we only could compare the species lists without considering the numbers of the observed individuals. Therefore our surveys were focused on the similarities vs. dissimilarities of the species composition of the whole assemblage, but also of the three most diverse families and three subfamilies of Noctuidae separately. Composition of the studied assemblages was compared by Principal Coordinate Analysis (PCoA) using the Jaccard and RogersTanimoto binary indexes. First is an unweighted index while in the other the nonmatch pairs (differential species) has double weight (Timm 2002). The analysis was carried out with SynTax 2000 program package (Podani 1997b). The proportions of the faunal types and ecological groups (faunal components) were also compared according to the biogeographical and ecological groupings used in the check list of the Macro-moths of Hungary (Varga et al. 2004). The taxonomy and nomenclature of the listed moths followed the book "Macrolepidoptera of Hungary" (Varga 2012).

\section{Results}

\section{Faunistical results}

The summarized check-list of the five studied sites contains 685 Macroheterocera species. The number of species per site generally varied around or over 500 with the exception of the Kaszonyi-hill where only 362 species were recorded (see Electronic supplementary file). This lower species richness was caused by lower sampling effort, since we could collect here only exceptionally at the very early spring (March), regularly from April to early October, and not at all in late autumn (November). Thus, the species number of Geometridae and among them especially of the Ennominae subfamily clearly showed this deficiency (Electronic supplementary file, Table 1). The species numbers of the other most diverse families Erebidae and Noctuidae were much more similar, including their subfamilies, and we also could not find any striking differences in the families with lower species numbers (e.g., Lasiocampidae, Sphingidae, Drepanidae, Tetheidae, Notodontidae, see Electronic supplementary file and Table 1).

As biogeographically most significant record we should mention the capture of the Pannonian endemic subspecies Apamea syriaca tallosi. This PontoMediterranean species occurred in all sites (5/5), and was considerably abundant in the Lónyai- and Bockerek forests. Beyond that we should highlight those species which are known from about or less than ten localities in Hungary, or from the Carpathian basin* at all, as Scopula nemoraria*, Lomaspilis opis* (Velyka Dobron'), Hypenodes pannonica*, Arytrura musculus* (Bátorliget), Parasemia plantaginis, Mniotype adusta (Lónyai-forest). Much more species show a typically restricted occurrence in the Carpathian basin, mostly in 
Table 1. Observed number of species in the Macroheterocera families and subfamilies at the sampling sites.

\begin{tabular}{|c|c|c|c|c|c|c|}
\hline & V. Dobron' & Bockerek & Lónyai-f. & Kaszonyi-h. & Bátorliget & Sum \\
\hline Geometridae & 155 & 155 & 164 & 92 & 175 & 226 \\
\hline Sterrhinae & 38 & 34 & 24 & 23 & 38 & 46 \\
\hline Larentiinae & 50 & 48 & 65 & 40 & 70 & 90 \\
\hline Ennominae & 56 & 62 & 62 & 21 & 53 & 74 \\
\hline Erebidae & 60 & 68 & 63 & 52 & 76 & 90 \\
\hline Herminiinae & 8 & 7 & 6 & 5 & 8 & 10 \\
\hline Lithosiinae & 10 & 13 & 12 & 10 & 13 & 15 \\
\hline Catocalinae & 15 & 15 & 13 & 10 & 16 & 20 \\
\hline Noctuidae & 210 & 199 & 219 & 165 & 197 & 280 \\
\hline Plusiinae & 12 & 7 & 13 & 9 & 11 & 15 \\
\hline Xyleninae & 86 & 89 & 88 & 55 & 72 & 116 \\
\hline Hadeninae & 39 & 36 & 41 & 38 & 42 & 49 \\
\hline Noctuinae & 30 & 28 & 23 & 22 & 30 & 41 \\
\hline Other Families & 69 & 79 & 71 & 53 & 75 & 89 \\
\hline Sum & 494 & 501 & 517 & 362 & 523 & 685 \\
\hline
\end{tabular}

the Northern Mountains (and of course, in the adjacent Carpathians): Xanthorrhoe quadrifasciata**, Spargania luctuata**, Ecliptopera capitata, Eulithis prunata, Chloroclysta siterata, Dysstroma truncata, Colostygia olivata**, Trichopteryx carpinata, Macaria brunneata, Gonodontis bidentata, Hydria undulata, Hypena crassalis, Autographa jota, A. pulchrina, A. bractea, Apamea crenata, A. epomidion, Dichagyris flammatra, Graphiphora augur, Diarsia brunnea, Anaplectoides prasina, Xestia ditrapezium, etc. The species signed with ** occurred only at Velyka Dobron'. The birch-alder specialists showed also a similar distribution with the difference that they also known to occur at the western-southwestern part of Hungary, as Drepana curvatula, Falcaria lacertinaria, Tethea fluctuosa, Achlia flavicornis, Plemyria bicolorata, Furcula furcula, Pheosia gnoma, Enargia paleacea, etc. As scarce food plant specialists we should mention Lamprotes c-aureum (Thalictrum spp.), Callopistria juventina (Pteridium aquilinum) and Gortyna borelii (Peucedanum officinale). Species connected with the enclosed marshy meadows as the widely distributed Euthrix potatoria, Eucarta virgo, E. amethysthina, Helotropha leucostigma, Hydraecia micacea, Denticucullus pygmina, Photedes fluxa, or the more locally distributed Amphipoea oculea, A. fucosa, Photedes extrema, Archanara dissoluta, A. neurica, Lenisa geminipuncta, also appeared at the studied sites. The oak woods had numerous characteristic species due to foodplant preference: Harpya milhauseri, Drymonia dodonaea, D. ruficornis, Spatalia argentina, Bena bicolorana, Catocala promissa, C. sponsa, Catephia alchymista, Minucia lunaris, Dryobotodes eremita, Agrochola laevis, etc. However, some of them as Cyclophora albiocellaria, C. suppunctaria, Schrankia taenialis, Jodia croceago, etc. were rather scarce. Other species were typical for the soft-wood (Salix, Populus) stands as Gastropacha populifolia, Cyclophora pendularia, Euchoeca nebulata, Pterapherapteryx sexalata, Furcula furcula, Earias clorana, Cosmia affinis, Ipimorpha retusa, I. subtusa, Agrochola lota, A. humilis, etc. There were some food-plant specialists also among the species con- nected to broadleaved trees (Acer, Fraxinus, Tilia), e.g., Cosmia diffinis, C. pyralina, Atethmia centrago, Tiliacea aurago and T. citrago. Other faunistically significant species feeding on shrubs of forest fringes were also sampled: Trichiura crataegi, Eriogaster catax, E. lanestris, Asthena anseraria, Apeira syringaria, etc. The presence of these species with mostly scarce distribution and special ecological needs showed the relatively high naturalness of the studied forests.

\section{Faunal components and faunal types}

The composition of the faunal components (ecological groups) showed the dominance of the species connected with some types of broadleaved forests as silvicolous and nemoral species which provide a total of $24.1-26.5 \%$ of the assemblages. Species of oakwood forests are represented in all sites with a ratio of near or over $10 \%$. Furthermore, about $10 \%$ of the assemblage is composed by willow-poplar and birch-alder species (Table 2). It means that about half of the complete assemblages consist of components of deciduous forested habitats (Fig. 2). The majority of the lichenophagous and litter feeding species also belong to the assemblage of these forests (Table 2, Fig. 2). Species of mesophilous and marshy-boggy (moor-marsh) meadows and humid tall forb communities are also represented with a total sum of about $20 \%$, but the ratio of generalists living in anthropogenic habitats did not reach $10 \%$. The steppicol and the migratory species are rather scarce excepting the Kaszonyi-hill where the ratio of steppicol species showed the third highest value (10.0\%) among different types. It means that despite of the fragmentation of forests and other natural habitats, the overwhelming majority of the Macroheterocera assemblage is constituted by the faunal components of a forested landscape (Table 2, Fig. 2).

Considering the biogeographical composition of the Macroheterocera assemblages, they were characterised by the dominance of the widely distributed Euro-Siberian species (about 50\%, Table 3, Fig. 3) but also with a significant presence (about 25\%) of Mediterranean species in wider sense (i.e., Holo- 
Table 2. The number of species and ratio (\%) of the faunal components in the Macroheterocera assemblages of the five studied sites.

\begin{tabular}{|c|c|c|c|c|c|c|c|c|c|c|}
\hline & \multicolumn{2}{|c|}{ Velyka Dobron' } & \multicolumn{2}{|c|}{ Bockerek } & \multicolumn{2}{|c|}{ Lónyai forest } & \multicolumn{2}{|c|}{ Kaszonyi-hill } & \multicolumn{2}{|c|}{ Bátorliget } \\
\hline & $\mathbf{N}$ & $\%$ & $\mathrm{~N}$ & $\%$ & $\mathrm{~N}$ & $\%$ & $\mathrm{~N}$ & $\%$ & $\mathrm{~N}$ & $\%$ \\
\hline Generalist & 73 & 14.8 & 73 & 14.6 & 75 & 14.0 & 65 & 17.6 & 76 & 14.5 \\
\hline Nemoral & 35 & 7.1 & 37 & 7.6 & 33 & 6.6 & 23 & 6.2 & 33 & 6.3 \\
\hline Silvicolous & 96 & 19.5 & 96 & 18.9 & 107 & 19.6 & 68 & 19.0 & 94 & 17.8 \\
\hline Oakwood & 49 & 9.9 & 56 & 11.2 & 49 & 9.4 & 36 & 9.7 & 39 & 7.5 \\
\hline Forest edge & 9 & 1.8 & 20 & 4.0 & 14 & 2.8 & 10 & 2.8 & 5 & 1.0 \\
\hline Willow-poplar & 44 & 8.9 & 41 & 8.2 & 43 & 8.6 & 27 & 7.6 & 42 & 8.0 \\
\hline Birch-alder & 11 & 2.2 & 9 & 1.9 & 9 & 1.8 & 4 & 1.1 & 12 & 2.3 \\
\hline Moor-marsh & 40 & 8.1 & 38 & 7.6 & 36 & 7.2 & 21 & 5.9 & 46 & 8.8 \\
\hline Altoherbosa & 26 & 5.3 & 19 & 3.8 & 31 & 6.2 & 15 & 4.2 & 29 & 5.6 \\
\hline Mesophilous & 37 & 7.5 & 29 & 5.8 & 33 & 6.6 & 30 & 8.4 & 43 & 8.2 \\
\hline Steppicol & 38 & 7.7 & 28 & 5.7 & 35 & 7.0 & 36 & 9.8 & 52 & 10.0 \\
\hline Arundiphilous & 7 & 1.4 & 13 & 2.6 & 10 & 2.0 & 2 & 0.6 & 14 & 2.7 \\
\hline Litter-feeding & 4 & 0.8 & 4 & 0.8 & 2 & 0.4 & 2 & 0.6 & 4 & 0.8 \\
\hline Lichenophagous & 8 & 1.6 & 10 & 2.0 & 10 & 2.0 & 7 & 2.0 & 12 & 2.3 \\
\hline Pine-sprouce & 1 & 0.2 & 5 & 1.0 & 6 & 1.2 & 2 & 0.6 & 5 & 1.0 \\
\hline Migratory & 14 & 2.8 & 9 & 1.9 & 9 & 1.8 & 10 & 2.8 & 7 & 1.3 \\
\hline Others & 2 & 0.4 & 14 & 2.4 & 16 & 2.8 & 4 & 1.1 & 10 & 1.9 \\
\hline
\end{tabular}

Explanations: Bold numbers show outstanding values by site.

Table 3. The number of species and ratio (\%) of the faunal types in the Macroheterocera assemblages of the five studied sites.

\begin{tabular}{|c|c|c|c|c|c|c|c|c|c|c|}
\hline & \multicolumn{2}{|c|}{ Velyka Dobron' } & \multicolumn{2}{|c|}{ Bockerek } & \multicolumn{2}{|c|}{ Lónyai forest } & \multicolumn{2}{|c|}{ Kaszonyi-hill } & \multicolumn{2}{|c|}{ Bátorliget } \\
\hline & $\mathbf{N}$ & $\%$ & $\mathrm{~N}$ & $\%$ & $\mathrm{~N}$ & $\%$ & $\mathrm{~N}$ & $\%$ & $\mathrm{~N}$ & $\%$ \\
\hline Holarctic & 7 & 1.4 & 7 & 1.4 & 7 & 1.4 & 4 & 1.1 & 8 & 1.5 \\
\hline Euro-Siberian & 258 & 52.3 & 252 & 50.2 & 274 & 52.3 & 209 & 57.8 & 281 & 53.7 \\
\hline Boreo-Continental & 88 & 17.9 & 88 & 17.6 & 96 & 18.6 & 42 & 11.3 & 97 & 18.6 \\
\hline European-E-Asiatic disjunct & 4 & 0.8 & 5 & 1 & 3 & 0.6 & 1 & 0.3 & 8 & 1.5 \\
\hline Ponto-Caspian-Manchurian & 7 & 1.4 & 7 & 1.4 & 7 & 1.4 & 6 & 1.7 & 10 & 1.9 \\
\hline Holo-Mediterranean-W-Asiatic & 25 & 5.1 & 27 & 5.4 & 21 & 4.2 & 21 & 5.9 & 21 & 4.0 \\
\hline Holo-Mediterranean & 82 & 16.7 & 86 & 17.2 & 90 & 17.5 & 61 & 16.8 & 77 & 14.8 \\
\hline Ponto-Mediterranean & 12 & 2.4 & 18 & 3.6 & 9 & 1.8 & 7 & 2 & 12 & 2.3 \\
\hline Extra-Palearctic & 10 & 2.0 & 11 & 2.2 & 11 & 2.2 & 11 & 3.1 & 9 & 1.7 \\
\hline
\end{tabular}

Explanations: Bold numbers show outstanding values by site.

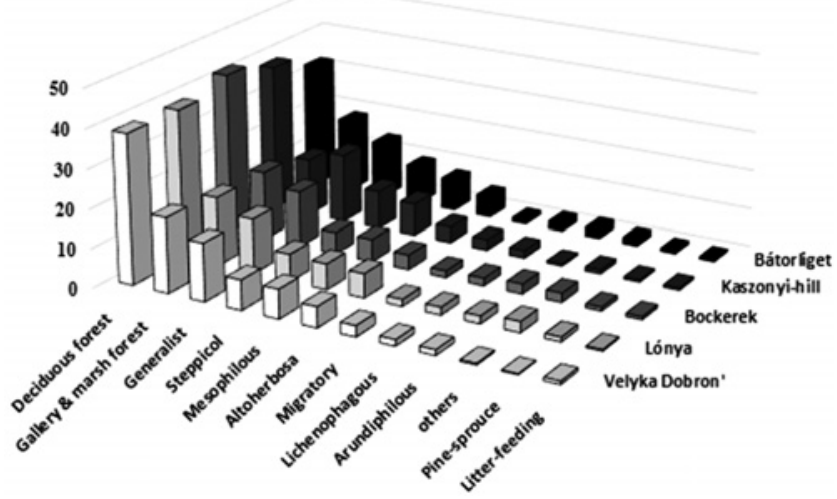

Fig. 2. Ratio of the main faunal components (\%) in the Macroheterocera assemblages of the five sites (see also Table 2).

Mediterranean-West Asiatic species, mostly occurring also in southern Central Europe). The BoreoContinental (over 10\%) and mostly the southern Continental (European-E-Asiatic disjunct, Ponto-CaspianManchurian) types were much less represented (below $5 \%$ ), although several faunistically significant species (as Euphya unangulata, Hydria undulata, Dysstroma

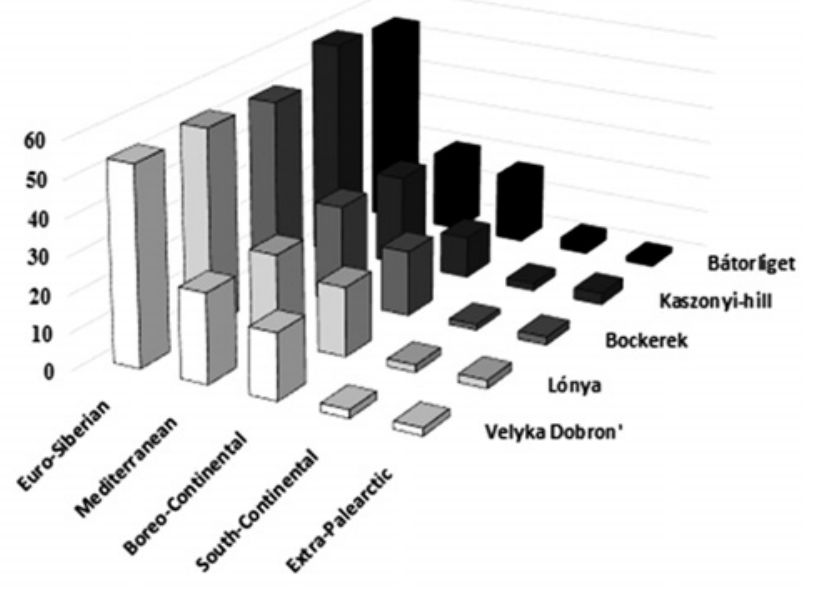

Fig. 3. Ratio (\%) of the main faunal types in the Macroheterocera assemblages of the five studied sites.

truncata, Macaria brunneata, Gonodontis bidentata, Hypena crassalis, Photedes extrema, Gortyna flavago, Enargia paleacea, Mythimna impura, Diarsia brunnea) belonged to the Boreo-Continental faunal type. 
Table 4. List and number (in parenthesis) of differential species (occurring only in one of the studied sites) of the Macroheterocera assemblages.

\begin{tabular}{ll}
\hline & Velyka Dobron' (18 species) \\
\hline Acherontia atropos (Linnaeus, 1758) & Trichoplusia ni (Hübner, 1803) \\
\hline Idaea subsericeata (Haworth, 1809) & $\begin{array}{l}\text { Heliothis nubigera Herrich-Schäff er, 1851 } \\
\text { Idaea dilutaria (Hübner, 1799) }\end{array}$ \\
Idaea rubraria (Staudinger, 1901) & Apamea unanimis (Hübner, 1813) \\
Scopula nemoraria (Hübner, 1799) & Apamea oblonga (Haworth, 1809) \\
Xanthorhoe quadrifasciata (Clerck, 1759) & Litoligia literosa (Haworth, 1809) \\
Colostygia olivata (Denis \& Schiffermüller, 1775) & Conistra ligula (Esper, 1791) \\
Lomaspilis opis Butler, 1878 & Euxoa obelisca ([Denis \& Schiffermüller], 1775) \\
Herminia tenuialis (Rebel,1899) & Agrotis clavis (Hufnagel, 1766)
\end{tabular}

Bockerek (24 species)

\begin{tabular}{ll}
\hline Lemonia dumi (Linnaeus, 1761) & Schrankia taenialis (Hübner, [1809]) \\
Achlya flavicornis (Linnaeus, 1758) & Nudaria mundana (Linnaeus, 1761) \\
Idaea politaria (Hübner, 1799) & Catocala hymenaea ([Denis \& Schiffermüller], 1775) \\
Cyclophora suppunctaria (Zeller, 1847) & Gortyna borelii lunata Freyer, [1838] \\
Anticlea badiata ([Denis \& Schiffermüller], 1775) & Lenisa geminipuncta (Haworth, 1809) \\
Eulithis mellinata (Fabricius, 1787) & Photedes morrisii (Dale, 1837) \\
Abraxas sylvata (Scopoli, 1763) & Episema tersa ([Denis \& Schiffermüller], 1775) \\
Isturgia roraria (Fabricius, 1777) & Lithophane furcifera (Hufnagel, 1766) \\
Epione vespertaria (Linnaeus, 1767) & Pachetra sagittigera (Hufnagel, 1766) \\
Furcula bicuspis (Borkhausen, 1790) & Dichagyris flammatra ([Denis \& Schiffermüller], 1775) \\
Drymonia velitaris (Hufnagel, 1767) & Euxoa hastifera (Donzel, 1847) \\
Drymonia obliterata Esper, 1785 & Rhyacia simulans (Hufnagel, 1766) \\
\hline
\end{tabular}

Lónyai-forest (21 species)

$\begin{array}{ll}\text { Boudinotiana notha (Hübner, 1803) } & \text { Hypena crassalis (Fabricius, 1787) } \\ \text { Eulithis prunata (Linnaeus, 1758) } & \text { Autographa jota (Linnaeus, 1758) } \\ \text { Pennithera firmata (Hübner, 1822) } & \text { Shargacucullia verbasci (Linnaeus, 1758) } \\ \text { Thera obeliscata (Hübner, 1787) } & \text { Cucullia fraudatrix Eversmann, 1837 } \\ \text { Perizoma albulata ([Denis \& Schiffermüller], 1775) } & \text { Phragmatiphila nexa (Hübner, 1808) } \\ \text { Eupithecia succenturiata (Linnaeus, 1758) } & \text { Archanara neurica (Hübner, 1808) } \\ \text { Aplocera eff ormata (Guenée, 1857) } & \text { Apamea illyria Freyer, 1846 } \\ \text { Odontopera bidentata (Clerck, 1759) } & \text { Polymixis polymita (Linnaeus, 1761) } \\ \text { Ourapteryx sambucaria (Linnaeus, 1758) } & \text { Mniotype adusta (Esper, 1790) } \\ \text { Idia calvaria ([Denis \& Schiffermüller], 1775) } & \text { Opigena polygona ([Denis \& Schiffermüller], 1775) } \\ \text { Hypena obesalis Treitschke, 1829 } & \end{array}$

Bátorliget (34 species)

Tethea duplaris (Linnaeus, 1661)

Pseudoterpna pruinata (Hufnagel, 1787)

Aplasta ononaria (Fuessly, 1783)

Rhodometra sacraria (Linnaeus, 1761)

Idaea emarginata (Linnaeus, 1758)

Horisme tersata ([Denis \& Schiffermüller], 1775)

Perizoma bifasciatum (Haworth, 1809)

Eupithecia inturbata (Hübner, 1799)

Eupithecia haworthiata Doubleday, 1856

Eupithecia exiguata (Hübner, 1799)

Eupithecia extraversaria (Herrich-Schäffer, 1855)

Eupithecia subfuscata (Haworth, 1809)

Eupithecia pyreneata Mabille, 1871

Tephronia sepiaria (Hufnagel, 1767)

Chariaspilates formosaria (Eversmann, 1837)

Pheosia gnoma (Fabricius, 1777)

Hypenodes humidalis Doubleday, 1850
Hypenodes pannonica Fibiger, Pekarsky \& Ronkay, 2010

Zanclognatha cribrumalis (Hübner, 1793)

Laelia coenosa (Hübner, 1808)

Phragmatobia caesarea (Goeze, 1781)

Coscinia cribraria (Linnaeus, 1758)

Setina roscida ([Denis \& Schiffermüller], 1775)

Pelosia obtusa (Herrich-Schäffer, [1852])

Arytrura musculus (Ménetries, 1859)

Catocala puerpera (Giorna, 1791)

Cucullia artemisiae (Hufnagel, 1766)

Cucullia absinthii (Linnaeus, 1758)

Cucullia balsamitae Boisduval, 1840

Staurophora celsia (Linnaeus, 1758)

Mythimna straminea (Treitschke, 1825)

Hadula dianthi hungarica (Wagner, 1913)

Panolis flammea ([Denis \& Schiffermüller], 1775)

Eugraphe sigma ([Denis \& Schiffermüller], 1775)
Faunal similarity and differential species

Similarity vs. dissimilarity in the composition of the studied assemblages was compared by Principal Coordinate Analysis (PCoA) using the unweighted Jaccard and Rogers-Tanimoto binary indexes which weights the differential species with double value (Podani 1997a; Timm 2002). The ordinations carried out with Jaccard index showed the highest similarity between the species assemblages of Velyka Dobron' (1) and Bockerek (2) in all comparisons (Figs 4,5). The high similarity values 


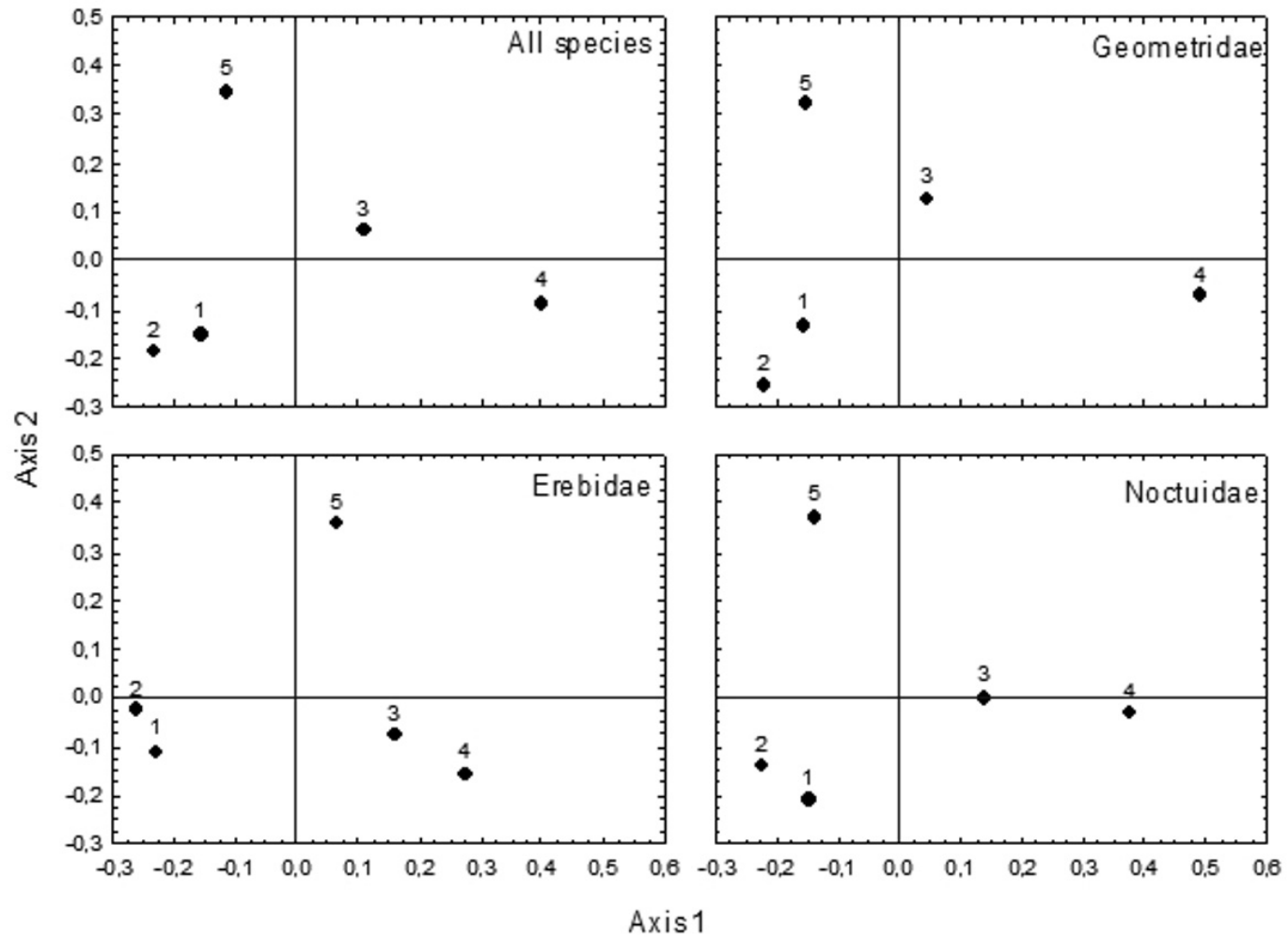

Fig. 4. Ordination of the assemblages according to the Jaccard index (unweighted), for all species and the three most diverse families separately. 1 - Velyka Dobron'; 2 - Bockerek, 3 - Lónyai forest; 4 - Kaszonyi-hill; 5 - Bátorliget. Percent variation explained: all species: Axis1 $=35.91 \%$, Axis2 $=25.64 \%$; Geometridae: Axis1 $=38.37 \%$, Axis2 $=23.74 \%$; Erebidae: Axis $1=35.86 \%$, Axis $2=$ $26.92 \%$; Noctuidae: Axis $1=34.48 \%$, Axis $2=27.89 \%$.

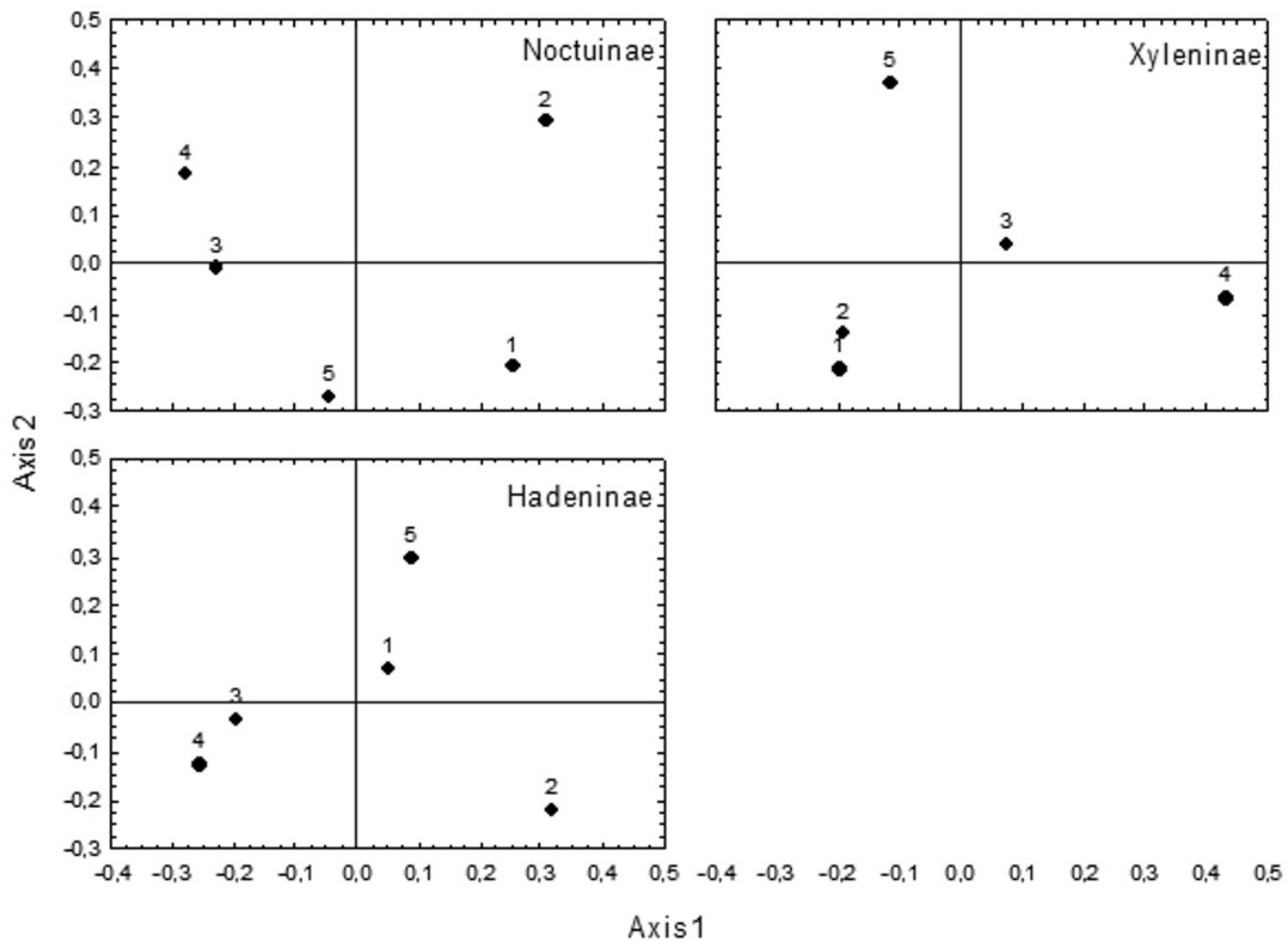

Fig. 5. Ordination of the three most diverse subfamilies of Noctuidae according to the Jaccard index (unweighted). 1 - Velyka Dobron'; 2 - Bockerek, 3 - Lónyai forest; 4 - Kaszonyi-hill; 5 - Bátorliget. Percent variation explained: Noctuinae: Axis1 = 37.03\%, Axis2 = $30.18 \%$; Xyleninae: Axis1 $=34.63 \%$, Axis2 $=26.22 \%$; Hadeninae: Axis1 $=40.05 \%$, Axis2 $=29.10 \%$. 
cover some important details of species composition. Although the Bockerek forest (2) belonged to the sites with the higher number of differential species (Table 3 ), but they possessed a large number (20) of such common species which did not occur in other sites. These mostly belong to Noctuidae family and connected to forest or marshy habitats.

All other sites showed moderate level of similarity (generally between $60-70 \%$ similarity according to the Jaccard index). While the similarity of Velyka Dobron' and Bockerek was the highest also in case of the three most diverse families, the near lying Lónyai-forest (3) and Kaszonyi-hill (4) show in this respect some differences. They proved to be fairly similar in the composition of Erebidae and Noctuidae but much less in Geometridae which can be explained with the higher number of nemoral and sylvicolous Geometridae species in the Lónyai-forest (Fig. 4). These relations were changed in the comparisons of the three most diverse subfamilies of Noctuidae. In case of Xyleninae consisting of mostly nemoral and silvicolous species high similarity was found between assemblages of Velyka Dobron' (1) and Bockerek (2) while in case of Hadeninae and Noctuinae the sites Lónyai-forest (3) and Kaszonyi-hill (4) showed the higher similarity and positioned closer to each other in the ordinations (Fig. 5). The site 5 (Bátorliget) was clearly separated from all other sites in all comparisons. These results were completely confirmed also by the ordinations using the weighted RogersTanimoto index (Figs 6, 7).

Despite of the general similarities in faunal composition, all sites had several differential species with the exception of the smallest and mostly fragmented Kaszonyi-hill (4) (Table 4). The biogeographical character and the ecological connections of the differential species showed some trends. Most northern (boreal) species, including some rare ones as Scopula nemoraria, Xanthorhoe quadrifasciata, Spargania luctuata (captured only by bait trap), Colostygia olivata, Lomaspilis opis and Apamea unanimis occured in Velyka Dobron' reserve (1). Other differential species belong however, to the thermophilous components (e.g., Idaea subsericeata, I. rubraria, Polyphaenis sericata, Litoligia literosa), these species are possibly connected with the more xerophilous part of the forest rich in Tilia tomentosa, Ligustrum vulgare and several steppic forest plant species. The second highest number of differential species (24) was observed in the Bockerek forest (2). The main speciality of this site was the presence of some species connected with birch and alder (Achlya flavicornis, Furcula bicuspis, Litophane furcifera), the occurrence of wetland species living on reed or sedges (Carex spp.) (Lenisa geminipuncta, Photedes morrisii) and also the appearance of montane forests species as Abraxas sylvata, Epione vespertaria, Drymonia obliterata and Rhyacia lucipeta. The moderately high number of differential species (21) of the Lónyai-forest (3) is mostly composed by species showing a colline-montane distribution in Hungary (Eulithis prunata, Perizoma albulata, Odontopera bidentata, Idia calvaria, Hypena obesalis, Hypena crassalis, Autographa jota, Apamea illyria, Mniotype adusta). The highest number of differential species (34) was observed in Bátorliget (5). These species belong to rather different ecological components from which the species of sandy areas (Cucullia artemisiae, C. absinthii, C. balsamitae, Staurophora celsia) and marshy-boggy habitats (Chariaspilates formosaria, Hypenodes humidalis, H. pannonica, Zanclognatha cribrumalis, Arytrura musculus, Laelia coenosa) were the most important. At the same time, some of them have an expressed relict-like character as the Pannonian endemic Hypenodes pannonica and Coscinia cribraria pannonica or the East European - East Asiatic disjunct Chariaspilates formosaria and Arytrura musculus (Table 4).

\section{Discussion}

\section{Species numbers}

The focal region belongs to the Pannonian lowland, however, it shows several differential traits both in climate (Baranyi 2009) and vegetation (Hargitai 1943; Simon 1957, 1960) from other parts of this large geographical unit. This region has a relatively coolcontinental climate and was originally overgrown by meso-hygrophilous deciduous forests. Therefore, we were mostly interested in, how these circumstances are reflected by the composition of the night-active moth assemblages. Furthermore, since the formerly nearly continuous forest cover of the region was strongly restricted by pastures, hayfields and arable lands and also dissected by drainage channels during the last oneand-half centuries, we expected that the potentially rich and highly diverse fauna possibly became seriously decimated and also some random changes could proceed in the ecological and biogeographical composition of the species assemblage.

Fortunately, these somewhat anxious expectations were not fulfilled. The species numbers proved to be relatively high compared to numerous other sites in the Carpathian Basin. The complete species list contains 685 species which can be compared with the macro-moth species list collected with the same method between 2007-2010 from 12 different sites of Transcarpathian Ukraine from the lowland to the alpine levels of Carpathians (Kanarskyi et al. 2011). However, the list of 534 species enumerated in the latter publication does not contain the Geometridae. Thus, the corresponding figure of our species list without Geometridae is 460 only. According to this publication the highest species number (399 spp.) was registered on a small hilly area near to our sites (BerehovoBeregszász) which is comparable with our data (Velyka Dobron': 355, Bockerek: 345, Lónyai-forest: 346, Bátorliget 349 species). The other two adjacent lowland sites from Transcarpathia show lower (248) or nearly equal (349) species numbers. Considering the most diverse family (Noctuidae s.l., incl. Erebidae without Lymantriinae, Arctiinae, Ctenuchinae and Lithosiinae), the species numbers are also comparable: from the 335 


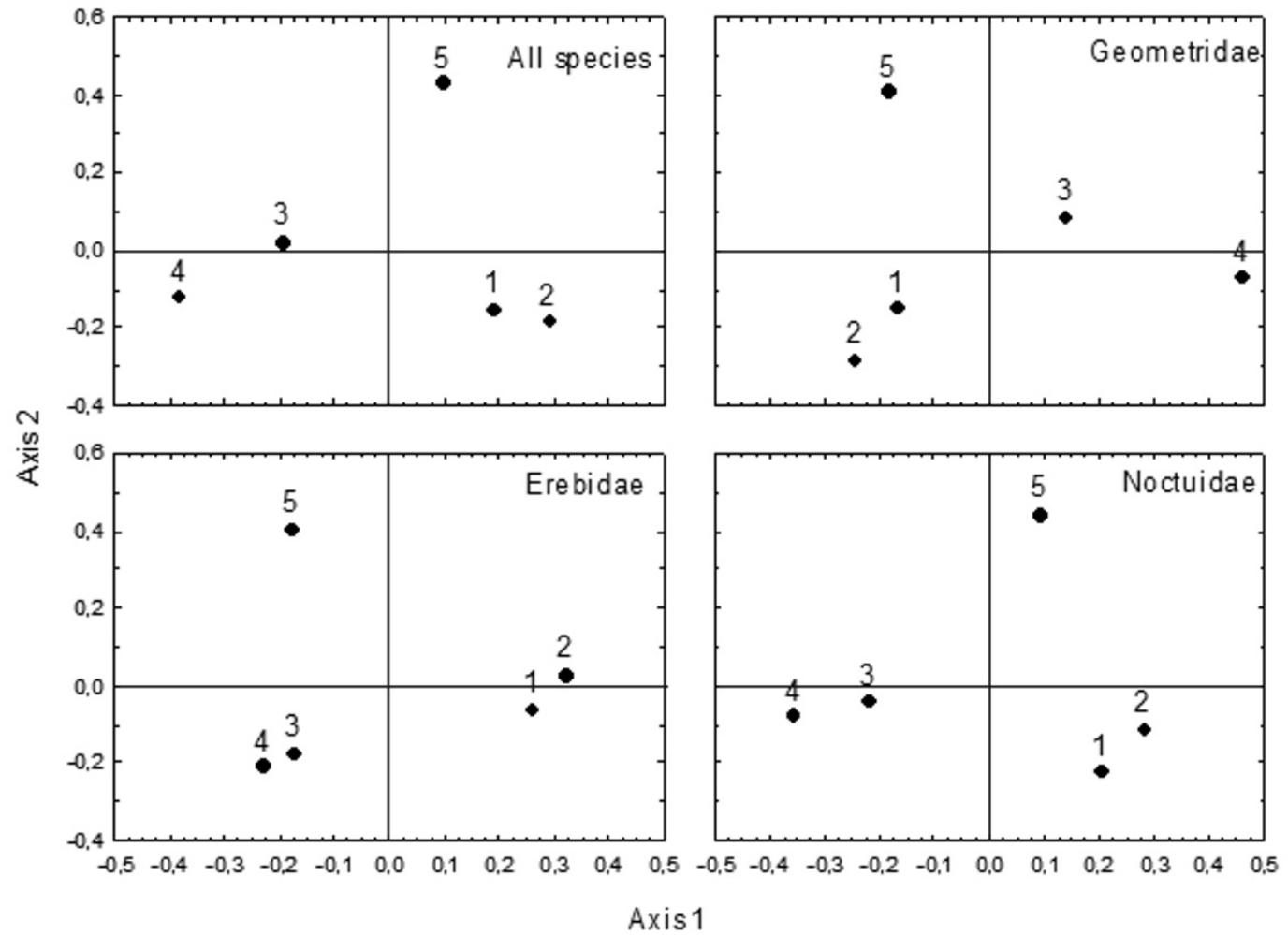

Fig. 6. Ordination of the assemblages according to the Rogers-Tanimoto index (double weigh to unmached pairs), for all species and the three most diverse families separately. 1 - Velyka Dobron'; 2 - Bockerek, 3 - Lónyai forest; 4 - Kaszonyi-hill; 5 -Bátorliget. Percent variation explained: All species: Axis $1=32.71 \%$, Axis2 = 26.98\%; Geometridae: Axis1 $=32.91 \%$, Axis2 = 26.25\%; Erebidae: Axis1 = $34.39 \%$, Axis $2=29.01 \%$; Noctuidae: Axis $1=32.22 \%$, Axis $2=27.71 \%$.

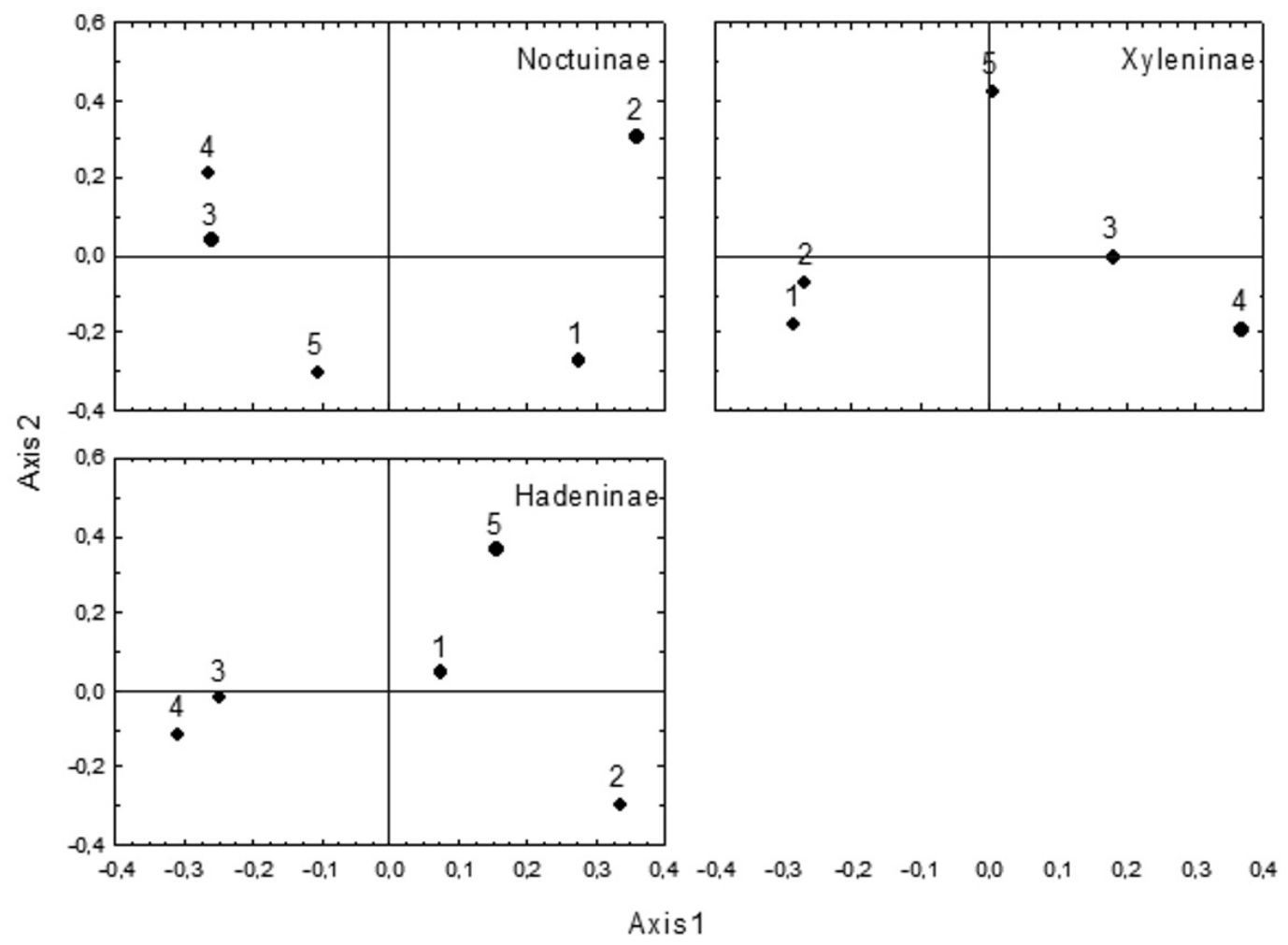

Fig. 7. Ordination of the three most diverse subfamilies of Noctuidae according to the Rogers-Tanimoto index (double weigh to unmached pairs). 1 - Velyka Dobron'; 2 - Bockerek, 3 - Lónyai forest; 4 - Kaszonyi-hill; 5 - Bátorliget. Percent variation explained: Noctuinae: Axis $1=35.67 \%$, Axis $2=30.66 \%$; Xyleninae: Axis1 $=31.73 \%$, Axis2 = 25.21\%; Hadeninae: Axis1 = 38.19\%, Axis2 = $29.49 \%$. 
species observed in Transcarpathia 286 species occur at the most diverse site near Berehovo-Beregszász, thus slightly more than in our mostly diverse sites (276 and 268) and nearly equal as in a similarly intensively surveyed site near to the Hungarian-Slovakian border (Jósvafo, 288 Noctuidae from the 594 macro-moth species, see Szabó et al. 2007). According to earlier light trap surveys (1961-1970) in Hungary, the highest species numbers were registered in colline levels of the Transdanubian (Várgesztes 275) and Northern Middle Range (Makkoshotyka 275) but the species numbers of most sites were below 250 species (Varga \& Gyulai 1976). It means that the moth assemblages of the Bereg lowland, probably due to its transitional situation, belong to those regions of the Carpathian basin which have the highest species diversity of Macro-moths.

\section{Biogeographical and ecological composition of assem-} blages, conclusions

Although the majority of the observed species is connected with forest habitats, main part of the faunistically significant species have herbaceous food plants (21 from the 28 species mentioned in the Results, e.g., Scopula nemoraria*, Xanthorrhoe quadrifasciata, Ecliptopera capitata, Dysstroma truncata*, Colostygia olivata, Parasemia plantaginis*, Mniotype adusta*, Diarsia brunnea, Anaplectoides prasina*, Xestia ditrapezium) and are characteristic for tall herb formations (Altoherbosa, as Autographa jota, A. pulchrina, A. bractea). Some of them have a wide Euro-Siberian distribution while others show a Boreo-continental (incl. Boreo-montane) character (see: *). The relatively numerous "birch-alder" species (e.g., Drepana curvatula, Falcaria lacertinaria, Tethea fluctuosa*, Achlia flavicornis*, Plemyria bicolorata*, Furcula bicuspis*, Pheosia gnoma*, Enargia paleacea*) generally have the same biogeographical character. Summing up, we can conclude that the assemblage of the surveyed forests despite of the fragmentation has sustained the basic character of a humid nemoral-boreal transitional fauna corresponding to the biogeographically transitional, Pannonian-Carpathian position of the Bereg lowland and surrounding northern edge of the Pannonian lowland. The transitional character is enhanced by the presence of the species of marshy-boggy habitats (Noctuidae: mostly Xyleninae, Apameini: Photedes, Denticucullus, Amphipoea, Globia, Archanara, etc.) but also by some species of (semi-)natural forest fringes (Trichiura crataegi, Eriogaster spp., numerous Geometridae) and by significant presence (about 25\%) of the Mediterranean species (in wider sense, mostly southern central European - West Asiatic species) often connected to decidous trees (Acer, Fraxinus, Tilia), components of the thermophilous mixed oak forests (e.g., Cosmia diffinis, C. pyralina, Atethmia centrago, Tiliacea aurago, T. citrago). Here should be mentioned that the oak woods of this region consist only of Quercus robur and $Q$. petraea (incl. $Q$. dalechampii), thus the species typical for $Q$. pubescens and $Q$. cerris stands were not observed in our study sites, although some of them were also registered in Transcarpathian xerothermic oak forests (see Kanarskyi et al. 2011; e.g., Phalera bucephaloides, Asteroscopus syriacus, Catocala conversa, C. nymphagoga, Dioszeghyana schmidtii). The studied sites were also relatively poor in typical "openland", steppic species (Idaea rufaria, I. subsericeata, Cucullia tanaceti, Episema glaucina, E. tersa, Litoligia literosa, Conisania luteago, Lacanobia aliena) although some others have already been observed in hilly habitats of the Ukrainian part of Transcarpathia (Cucullia xeranthemi, C. asteris, C. gozmanyi, Chersotis rectangula). In this respect we can compare the proportions of the faunal elements and ecological components of the Noctuoidea recorded in the Transcarpathian sites Berehovo-Beregszász and Velyka Dobron'-Nagydobrony. Since the widely distributed Euro-Siberian species is less represented in the former site (41.6 vs. $56 \%$ ), all biogeographically significant groups show somewhat higher contributions there than in Velyka Dobron'-Nagydobrony (Mediterranean s.l. 28.6 vs. 20.2; Boreo-Continental 22.2 vs. 17.8; Southern Continental 5.2 vs. 2). The ecological components also show similar general trends characterised by lower proportion of generalists (14 vs. 19\%) and "forest" s.l. components (summarized proportions are 35.9 vs. $42.4 \%$ ) but higher representation of steppic species (14.6 vs. $4.5 \%$ ) at Berehovo-Beregszász (vs. Velyka Dobron'Nagydobrony).

It means that the rich and relatively uniform composition of the moth assemblages does not refer to a significant decrease of species diversity or a random change of faunal types and components. Supposedly, if could be proceeded some changes in habitats they would be too recently to result in essential or simply measurable changes. The clearly separated position of the site 5 (Bátorliget) in all ordinations is obviously the consequence that this site belong to another smaller regional unit (Nyírség) with different edaphic conditions and partly different vegetation. In connection with the high species diversity and relatively natural stage of the studied forests we should mention that during our surveys no mass occurrence of the known pest species (as Lymantria dispar, Euproctis chrysorrhoea, late autumnal Geometridae) was observed. Of course, the timespan of the survey was too short for any generalisations.

The last question is the conservation biological evaluation of the studied assemblages. We consider the high general diversity of the moth fauna and the relatively high naturalness of their habitats as the main values. There are also some species enumerated in the Annexes of the Habitats Directive (Eriogaster catax, Proserpina proserpina, Euplagia quadripunctaria, Arytrura musculus* ${ }^{*}$ Gortyna borelii*). However, they were mostly observed in single or few specimens or only at a single site* since their most important habitats are extended outside of the surveyed sites. Thus, their presence cannot be over- or underestimated since the moths are generally underrepresented in the Annexes compared to the butterflies. 


\section{Acknowledgements}

Szabolcs Szanyi was supported by the "NTP-EFÖ-P-15 Programme". We are grateful to Dr. György Csóka and Levente Szőcs for sampling data of Bockerek. The assistence of Krisztián Katona in the field work is also highly appreciated.

\section{References}

Baranyi B. (ed.). 2009. Kárpátalja [Transcarpathia - in Hungarian]. A Kárpát-medence régiói. Die Regionen des KarpatenBeckens. Bd. 11: Karpaten-Ukraine. Dialóg Campus Kiadó, Pécs-Budapest, 541 pp. ISBN: 9789639899186

Boros Á. 1964. A tőzegmoha és a tőzegmohás lápok Magyarországon [Sphagnum and peat bogs in Hungary]. Vasi Szemle 18 (1): $53-68$

Deli T., Sümegi P. \& Kiss J. 1997. Biogeographical characterisation of the Mollusc fauna on Szatmár-Bereg Plain, pp. 123129. In: Tóth E. \& Horváth R. (eds), Proceedings of the "Research Conservation, Management" Conference (Aggtelek) 15 May 1966, ANP Füzetek Aggtelek Vol. I., 500 pp.

Fekete G. \& Varga Z. (eds). 2006. Magyarország tájainak növényzete és állatvilága [Vegetation and fauna of the landscapes in Hungary]. MTA Társadalomkutató Központ, Budapest, $460 \mathrm{pp}$.

Gálik K., Deli T. \& Sólymos P. 2001. Comparative malacological investigations on the Kaszonyi Hill (NE Hungary). Malakológiai Tájékoztató 19: 81-88.

Hargitai Z. 1943. Adatok a beregi sík erdeinek ismeretéhez. Debreceni Szemle 17 (3): 64-67.

Kanarskyi Y., Geryak Y. \& Lyashenko E. 2011. Ecogeographic structure of the moth fauna (Lepidoptera, Drepanoidea, Bombycoidea, Noctuoidea) in upper Tisa River basin and adjacent areas (Ukraine). Transylv. Rev. Syst. Ecol. Res. 11: "The Upper Tisa River Basin", pp. 143-168.

Kormány Gy. 1976. Szabolcs-Szatmár megye éghajlata [The climate of the County Szabolcs-Szatmár]. Szabolcs-Szatmári Szemle 1: $32-40$.

Ködöböcz V. \& Magura T. 1999. Biogeographical connections of the carabid fauna (Coleoptera) of the Beregi-síkság to the Carpathians. Folia Entomol. Hung. 60: 195-203.

Magura T., Ködöböcz V., Tóthmérész B., Molnár T., Elek Z. Szilágyi G. \& Hegyessy G. 1997. Carabid fauna of the Beregisíkság and its biogeographical relations (Coleoptera Carabidae). Folia Entomol. Hung. 58: 73-82.

Nagy A., Batiz Z. \& Szanyi Sz. 2015. Orthoptera fauna of the Hungarian part of the Bereg Plain (Northeast Hungary). Buletin de Informare Entomologica 26: 64-80.

Podani J. 1997a. Bevezetés a többváltozós biológiai adatfeltárás rejtelmeibe avagy "Mit is kezdjünk azzal a rengeteg adattal?" [Introduction to the multivariate statistics of biological data]. Scientia, Budapest, 658 pp. ISBN: 9638326069
Podani J. 1997b. SYNTAX 5.1.: A new version of PC and Macinthosh computers. Coenoses 12 (2/3): 149-152.

Simon T. 1957. Az Északi-Alföld erdői [The forests of the Northern Lowland]. Akadémiai kiadó, Budapest, 172 pp.

Simon T. 1960. Die Vegetation der Moore in den Naturschutzgebieten des Nördlichen Alföld. Acta Bot. Acad. Sci. Hung. 6: $249-252$.

Szanyi Sz. 2015. Egy kárpátaljai erdőrezervátum jellemzése az éjjeli nagylepkefauna alapján [Characterisation of a Transcarpathian forest reserve based on night-active moths]. Acta Naturalia Pannonica 8: 91-110.

Szanyi Sz., Katona K., Rácz I., Varga Z. \& Nagy A. 2015. Orthoptera fauna of the Ukrainian part of the Bereg Plain (Transcarpathia, Western Ukraine). Articulata 30 (1): 91104.

Szanyi Sz. \& Varga Z. 2014/15. Changes in butterfly assemblages of meadows in a Transcarpathian game reserve. Entomol. Roman. 19: $41-50$.

Timm N. H. 2002. Applied Multivariate Analysis. Springer, New York, 695 pp. DOI: 10.1007/b98963. ISBN: 978-0-387-95347-2

Varga Z. 1995. Geographical Patterns of Biodiversity in the Palearctic and in the Carpathian Basin. Acta Zool. Acad. Sci. Hung. 41 (2): 71-92.

Varga Z. 2003. A Kárpát-medence állatföldrajza [The zoogeography of the Carpathian basin], pp. 89-119. In: Láng I., Bedő Z. \& Csete L. (eds), Növény, állat, élőhely [Plants, Animals, Vegetation], Magyar Tudománytár III., MTA Társadalomkutató Központ, 590 pp. ISBN: 963-09-4359-X, 978-963-09-4359-8

Varga Z. (ed). 2012. Magyarország nagylepkéi - Macrolepidoptera of Hungary. Heterocera Press, Budapest, 253 pp. ISBN: 978963-88014-5-6

Varga Z. \& Gyulai I. 1978. Die Faunenelemente-Einteilung der Noctuiden Ungarns und die Verteilung der Faunenelemente in den Lokalfaunen. A magyarországi bagolylepkék faunaelembeosztása és az egyes faunaelemek megoszlása a helyi faunákban (Lepidoptera: Noctuidae). Acta Biol. Debrecina 15: 257295.

Varga Z., Ronkay L., Bálint Zs., László M. Gy. \& Peregovits L. 2004. A magyar állatvilág fajjegyzéke, 3. köt., Nagylepkék [Checklist of the fauna of Hungary. Vol. 3, Macrolepidoptera]. Hungarian Natural History Museum, Budapest, 106 pp. ISBN-10: 9637093885, ISBN-13: 978-9637093883

Zólyomi B. 1958. Budapest és környékének természetes növénytakarója [The natural vegetation of Budapest and its environment], pp. 511-642. In: Pécsi M. (ed.), Budapest földrajza [The geography of Budapest], Akadémiai Kiadó, Budapest. $744+8$ (map) pp.

Received May 27, 2016

Accepted October 15, 2016 